\title{
The role of family support and internal locus of control in entrepreneurial intention of vocational high school students
}

\author{
Dewi Niki Annisa, Fatwa Tentama, Khoiruddin Bashori
}

Faculty of Psychology, Universitas Ahmad Dahlan, Yogyakarta, Indonesia

\begin{tabular}{l} 
Article Info \\
\hline Article history: \\
Received Aug 17, 2020 \\
Revised Mar 5, 2021 \\
Accepted Apr 6, 2021 \\
\hline
\end{tabular}

\section{Keywords:}

Entrepreneurial intention Family support Internal locus of control

\begin{abstract}
This study examined the relationship between family support and internal locus of control with entrepreneurial intention among grade XII students attending Muhammadiyah 3 Vocational High School. From 172 grade XI students attending the school, 93 were selected to participate in the study. This study used a cluster-sampling technique. The data was collected using the entrepreneurial intention scale, the family support scale, and the internal locus of control scale. Multiple regression techniques were used to analyze the data on SPSS 19.0. The results indicated very significant positive relationship between family support and internal locus of control with entrepreneurial intention, family support with entrepreneurial intention, and internal locus of control with entrepreneurship intention. Thus, it can be inferred that the contribution of internal locus of control to entrepreneurial intention is more dominant than family support's contribution.
\end{abstract}

This is an open access article under the CC BY-SA license.

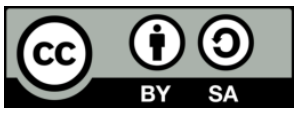

Corresponding Author:

Fatwa Tentama

Faculty of Psychology

Universitas Ahmad Dahlan

Kapas Street 9, Umbulharjo, Yogyakarta, Indonesia

Email: fatwa.tentama@psy.uad.ac.id

\section{INTRODUCTION}

In 2018, Central Bureau Statistics [1] released that 5.13\% of the Indonesian population, or 6.87 million people, are in open unemployment. Based on the educational background, vocational high school graduates contribute to the highest unemployment rate at $8.92 \%$. The number of unemployed vocational high school graduates is particularly high due to an imbalance between vocational high schools' education curriculum and the number of work demand from the industrial and service sectors [2]. That problem is contrary to the expectation of establishing vocational high schools which is to create work-ready graduates [3]. One way to reduce unemployment is the development of entrepreneurship [4]. In addition to bringing a solution for unemployment, entrepreneurship is also a measure of economic growth and development in a country [5]. The development of entrepreneurial interest and skills is crucial; thus, there is a need for entrepreneurship education to interest students' interest in developing a business enterprise, otherwise known as entrepreneurial intention [6].

Entrepreneurial intention is individuals' desire to carry out entrepreneurial activities by developing new business through existing business opportunities [7]. Entrepreneurial intention allows individuals to have a positive attitude and behavior regarding various risks in entrepreneurship [8]. Individuals who possess entrepreneurial intention can deliberate about and develop new business ventures [9]. Entrepreneurial intention consists of four dimensions, namely: 1) Desire, which is the internal drive in the form of interest and desire to start a business; 2) Preferences, which is the sense that entrepreneurship attainment is a 
necessity; 3) Plans, which is a desire to start a business in the future; 4) Behavior expectancies, which is the possibility for entrepreneurship followed by a goal of starting a business.

Students with high entrepreneurial intention have a positive attitude towards entrepreneurship [10], strive to turn entrepreneurial intention into entrepreneurial behavior [11], demonstrate entrepreneurial activities [12], are ready to face entrepreneurship risks [13], and can establish a business venture in the future [14]. Conversely, students with low entrepreneurial intention tend to have unfavorable perceptions about the various risks that one must face in entrepreneurship [15], are confused when faced with entrepreneurship opportunities [16], and give up easily when encountering entrepreneurial obstacles [17]. In a broader sense, low entrepreneurial intention lead to lower employment [18].

Various factors influence entrepreneurial intention, one of which is social support [19]-[21]. Social support is the perception or experience of being loved, cared for, valued, and supported by others [22]. Among the various type of social support, one that has been found to influence entrepreneurial intention is family support [23]. Family support is defined as a family's behavior and attitude in accepting its family members, which can take emotional, informational, and instrumental support [24]. Support can provide physical and psychological comfort in dealing with stress [25] and can also take motivation, advice, information, and real help [26].

Sarafino and Smith [27] suggested that family support includes several aspects, namely: 1) Emotional support, which involves expression of feelings, empathy, and attention to an individual, allowing one to feel comfortable, loved and cared for; 2) Appreciation support, which is a positive evaluation towards other's ideas, feelings, and performance, manifested through expressions of respect for family members; 3 ) Instrumental support, involving family members as a source of aid and unswerving supporting, can take the form of supervision, fulfillment of personal needs, as well as financial assistance or help in completing a task; 4) Informative support, which can take the form of information, advice, guidance, and feedback on how to solve a particular problem.

Supportive families tend to increase togetherness over time and become sources of support for each other [23]. Family support in the entrepreneurial context can take the form of information as well as help in acquiring or providing venture capitals, especially financial capitals [28]. Family support eases individuals in deciding to start a business, providing a boost of confidence in their abilities [29], as well as a positive appraisal of their decisions [30].

In addition to family support, another factor that can influence entrepreneurial intention are personality factors [31]. One dimension of personality that influences entrepreneurial intention is an internal locus of control [32]. Internal locus of control is the belief that every event that occurs to oneself is caused by factors that exist in his or herself [33]. Individuals who believe that their actions result in life happenings tend to believe that: they can control the results of their efforts [34], a particular action can produce the expected results [35], and one can determine his or her destiny and achievements [36], [37].

Individuals who have an internal locus of control are characterized by their: 1) Ability, defined as the mastery of a skill or the potential to master a skill, which is believed to determine the outcome of their success and failure; 2) Effort, meaning that individuals tend to be optimistic, have a never-give-up attitude and try their best to control behavior so that they can realize their desires [38].

Individuals who have a clear vision of their future will strive to realize their desires for entrepreneurship [39], [40]. Also, strong self-control leads individuals to believe that their quality of life is self-determined; thus, the willingness to work hard for success [41]. In the entrepreneurial context, individuals with an internal locus of control have a higher chance of undertaking entrepreneurial activities and starting new businesses [31]. Based on the above explanation, the relationship between family support, internal locus of control, and entrepreneurial intention can be illustrated through as shown in Figure 1.

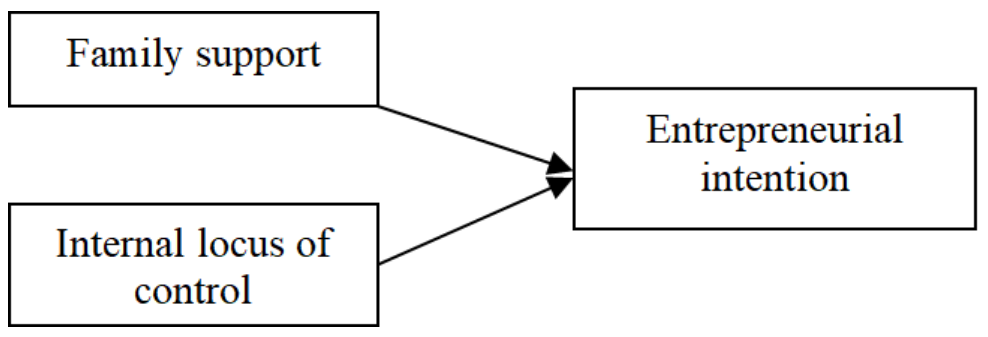

Figure 1. The relationship between family support, internal locus of control and entrepreneurial intention 
Based on the description of the problem background, which is also supported by the results of previous studies, the researcher intended to explore further the relationship between family support and internal locus of control with the entrepreneurial intention grade XII students of Muhammadiyah 3 Vocational High School.

\section{RESEARCH METHOD}

\subsection{Population and sample}

The population of this study was 172 grade XII students of Muhammadiyah 3 Vocational High School. The total class is seven classes. The sample of this study were 93 students. This study used a cluster random sampling technique conducted by randomizing students from each class.

\subsection{Instruments}

Data collection was conducted using psychological scales as research instruments, namely the entrepreneurial intention Scale, the family support scale, and the internal locus of control scale. Tentama and Abdussalam [42] developed the entrepreneurial intention scale by referring to the dimensions of entrepreneurship intention according to Gelderen, et al. [43], namely desires, preferences, plans, and behavior expectancies. The Entrepreneurial Intention Scale used the Likert Scale to measure its intended variable. Examples of the scale of entrepreneurial intention are: "I aspire to become an entrepreneur," "I like things related to the world of entrepreneurship," and "I plan to expand my knowledge about independent business enterprise."

The family support scale is developed based on aspects of family support suggested by Sarafino and Smith [27], namely emotional support, appreciation support, instrumental support, and informative support. The scaling model used in the family support scale is the Likert Scale. An example of a family support scale includes: "my family respects my opinions," "my family provides the facilities that I need," and "my parents provide the best advice when I am in trouble."

The internal locus of control scale is constructed based on the dimensions of internal locus of control proposed by Lefcourt [34], namely ability and effort. The scaling model used in the Internal Locus of Control Scale is the Likert Scale. Example of items in the Internal Locus of Control Scale includes: "my ability to determine my success," "doing the task with maximum effort will help complete the task quickly," and "I am able to resolve occurring conflicts."

\subsection{Validity and reliability}

A pilot testing of the instruments was conducted with 60 students. Results of the pilot testing indicate of instruments that the entrepreneurial intention scale obtained a reliability coefficient $(\alpha)$ of 0.868 . The item discriminant power (corrected item-total correlation) ranged between 0.447 to 0.707 . The study produced 12 valid and reliable items. Secondly, the family support scale obtained a reliability coefficient $(\alpha)$ of 0.957 . The item discriminant power (corrected item-total correlation) ranged between 0.450 and 0.831 . The study produced 28 valid and reliable items. Finally, the pilot testing results on 60 students showed that the internal locus of control scale obtained a reliability coefficient $(\alpha)$ of 0.860 . The item discriminant power (corrected item-total correlation) ranged between 0.352 to 0.677 . The study produced 14 valid and reliable items.

\subsection{Data analysis}

Data analysis was conducted using parametric statistical analysis. Multiple regression analysis was conducted on SPSS 19.0 for Windows to examine the relationship between family support and internal locus of control with entrepreneurial intention. The assumption tested before analysis are the normality test, linearity test, and multicollinearity test.

\section{RESULTS AND DISCUSSION}

\subsection{Assumptions testing}

\subsubsection{Normality test}

Based on the normality test seen in Table 1, the significance value of each variable are: entrepreneurial intention at 0.129 ( $p>0.05)$, family support at 0.100 ( $p>0.05)$, and internal locus of control at 0.072 ( $p>0.05)$. Based on the normality test, it can be concluded that all variables in this study are normally distributed. 


\begin{tabular}{lccc}
\multicolumn{4}{c}{ Table 1. Results of normality test } \\
\hline \multicolumn{1}{c}{ Variable } & Score K-SZ & Sig. & Annotation \\
\hline Entrepreneurial intention & 0.083 & 0.129 & Normal \\
Family support & 0.084 & 0.100 & Normal \\
Internal locus of control & 0.088 & 0.072 & Normal \\
\hline
\end{tabular}

\subsubsection{Linearity test}

Linearity test aims to determine which two variables have a significant linear relationship. Based on Table 2, the linearity test results on entrepreneurial intention and family support acquired an F of 0.451 and p-value of $0.000(\mathrm{p}<0.05)$, indicating a linear relationship between the two variables. The relationship between entrepreneurial intention and internal locus of control obtained F of 0.919 and p-value of 0.000 $(\mathrm{p}<0.05)$, indicating a linear relationship between entrepreneurial intention and linear internal locus of control. Based on these results, it can be concluded that the data in this study meet the linearity requirements.

Table 2. Results of linearity test

\begin{tabular}{lccc}
\hline Variable & F linearity & Sig. & Annotation \\
\hline Entrepreneurial intention and family support & 0.451 & 0.000 & Linear \\
Entrepreneurial intention and internal locus of control & 0.919 & 0.000 & Linear \\
\hline
\end{tabular}

\subsubsection{Multicollinearity test}

Based on the multicollinearity test results in Table 3, family support and internal locus of control obtained a VIF value of $1.883(\mathrm{VIF}<10)$ and a tolerance value of 0.531 (tolerance $>0.1)$. Thus, there is no multicollinearity or low correlations between family support and internal locus of control.

Table 3. Result of multicollinearity test

\begin{tabular}{lccc}
\hline \multicolumn{1}{c}{ Variable } & Tolerance & VIF & Annotation \\
\hline Family support & 0.531 & 1.883 & No multicollinearity \\
Internal locus of control & 0.531 & 1.883 & No multicollinearity \\
\hline
\end{tabular}

\subsection{Hypothesis testing}

The data analysis results in Table 4 shows that there is a relationship between family support and entrepreneurial intention with $\mathrm{r}=0.37(\mathrm{p}<0.01)$, meaning that partially, there is a positive and very significant relationship between family support and entrepreneurial intention. The relationship between internal locus of control and entrepreneurial intention obtained $r=0.504(p<0.01)$, meaning that partially, there was a positive and very significant relationship between internal locus of control and entrepreneurial intention.

The results of the multiple linear regression analysis as shown in Table 5, simultaneously, family support and internal locus of control have a very significant relationship with entrepreneurial intention in students of Muhammadiyah 3 Vocational High School. These results indicate that the first hypothesis is accepted, thereby inferring that family support and internal locus of control can predict entrepreneurial intention. Simultaneously, the two independent variables contribute $28 \%$ to entrepreneurial intention, while other factors possibly influence $72 \%$. Other factors that can influence entrepreneurial intention include the need for achievement and subjective norms [44], sense of worthiness as entrepreneurs and entrepreneurship barriers [45], educational support [21], entrepreneurship education [46] and entrepreneurial exposure [47]. The contribution of family support and internal locus of control to entrepreneurial intention is $7.28 \%$ and $21.1 \%$. Thus, it can be inferred that the contribution of internal locus of control to entrepreneurial intention is more dominant than family support's contribution.

Table 4. Partial hypothesis test

\begin{tabular}{lcccc}
\hline Variable & $\mathrm{r}$ & Sig. & Criteria & Annotation \\
\hline Family support and entrepreneurial intention & 0.371 & 0.000 & $\mathrm{p}<0.01$ & Very significant relationship \\
Internal locus of control and entrepreneurial intention & 0.504 & 0.000 & $\mathrm{p}<0.01$ & Very significant relationship \\
\hline
\end{tabular}




\begin{tabular}{lccccc}
\multicolumn{7}{c}{ Table 5. Simultaneous hypothesis testing } \\
\hline \multicolumn{1}{c}{ Variable } & $\mathrm{R}$ & $\mathrm{R}$ Square & Sig. & Criteria & Annotation \\
\hline $\begin{array}{l}\text { Family support and internal locus of control } \\
\text { towards entrepreneurial intention }\end{array}$ & 0.529 & 0.280 & 0.000 & $\mathrm{p}<0.01$ & $\begin{array}{c}\text { Very significant } \\
\text { relationship }\end{array}$ \\
\hline
\end{tabular}

The results indicate that the second hypothesis is accepted, meaning that there is a very significant relationship between family support and entrepreneurial intention in Muhammadiyah 3 Vocational High School students. This result is in line with previous research which also found that family support predicts entrepreneurial intention [48]-[51]. Students have a higher entrepreneurial intention when they have the support needed to establish an enterprise [52].

Family support is crucial, particularly for students whose wants are strongly influenced by family support, both emotionally and financially [23], [53]. Students who have high emotional support tend to have stronger entrepreneurial aspirations due to the belief that their families can support them during the various cycles of entrepreneurship, which are often unpredictable [54]. Students who receive from the families' support in the form of information regarding entrepreneurship have relatively vast knowledge leading them to become more confident in entrepreneurship [55], [56].

The results also indicate that the third hypothesis is accepted, meaning that there is a very significant relationship between internal locus of control and entrepreneurial intention in Muhammadiyah 3 Vocational High School students. This result is in line with previous research, which also found that internal locus of control can predict entrepreneurial intention [57]-[60]. Students with a high internal locus of control believe that their lives are self-determined, thereby leading them to have had the confidence to determine the career path they desire, by being better and bolder in starting business ventures [60].

Students who believe that they can strive to achieve their desires will attempt to realize their entrepreneurial intention [61] and do things that are considered to bring entrepreneurial success [32]. Belief in this context consists of students' belief of becoming entrepreneurs and the belief that the entrepreneurship results can be controlled through various efforts [62]. Through these beliefs, students subsequently build a stronger desire for entrepreneurship.

The findings of this study are different from previous studies. The results of previous studies on entrepreneurial intentions indicate that the factors that influence entrepreneurial intention are entrepreneurship education [63], self-efficacy and family support [64], subjective norms and hardiness [65] and entrepreneurial training [66]. This research is expected to complement previous research to make it more comprehensive. This study implies that students who have entrepreneurial intention require internal and external factors to realize entrepreneurial behaviours. Students must attempt to develop their internal locus of control because it is a dominant internal factor that influences entrepreneurial intention. However, internal factors must also have the backing of external factors, namely family support to encourage the formation of students' entrepreneurial intention to its maximum.

\section{CONCLUSION}

To be able to apply their learning outcomes upon graduation, the entrepreneurial intention has, in recent times, become a crucial need for students of Muhammadiyah 3 Vocational High School. Students need to pay attention to both external and internal factors in developing entrepreneurial intention, namely family support and internal locus of control. Simultaneously, there is a very significant relationship between family support and internal locus of control with entrepreneurial intention in students. Partially, there is very significant positive relationship between family support and entrepreneurial intentions in students, as well as very significant positive relationship between internal locus of control and entrepreneurial intention in students. Family support and internal locus of control contribute to entrepreneurial intention. The most dominant contribution is internal locus of control as an internal factor.

\section{ACKNOWLEDGEMENTS}

The authors would like to thank the Psychology Masters Study Program, Universitas Ahmad Dahlan, and Muhammadiyah 3 Vocational High School, which have provided excellent support and services to carry out this research. 


\section{REFERENCES}

[1] Central Bureau Statistics, Indonesian Labor Situation February 2018 (in Bahasa), 2018

[2] G. J. Soputan, “Are Vocational High School Students Ready to be Entrepreneur?" Innovation of Vocational Technology Education, vol. 13, no. 2, pp. 45-49, 2017, doi: 10.17509/invotec.v13i2.8264.

[3] Y. G. D. Utami and Hudaniah, "Self-efficacy with Vocational High School Students' Job Readiness," (in Bahasa), Jurnal Ilmiah Psikologi Terapan, vol. 1, no. 1, pp. 40-52, 2013. [Online]. Available: https://ejournal.umm.ac.id/index.php/jipt/article/view/1356.

[4] A. Asad, H. M. Ali and U. Islam, "The Relationship between Entrepreneurship Development and Unemployment Reduction in Pakistan," Global Journal of Management and Business Research, vol. 14, no. 10, 2014. [Online]. Available: https://journalofbusiness.org/index.php/GJMBR/article/view/1486.

[5] W. Naudé, "Entrepreneurship Is Not a Binding Constraint on Growth and Development in The Poorest Countries," World Development, vol. 39, no. 1, pp. 33-44, 2011, 10.1016/j.worlddev.2010.05.005.

[6] A. Agung, A. Mukhadis, E. Sutadji, and P. Purnomo, "Entrepreneurship Intent on Vocational High School Education: The growth of new Entrepreneurs in Indonesia," International Conference on Indonesian Technical Vocational Education and Association (APTEKINDO 2018). Atlantis Press, vol. 201, 2018, pp. 279-300, doi: 10.2991/aptekindo-18.2018.65.

[7] T. Ramayah and Z. Harun, "Entrepreneurial Intention among University Sains Malaysia (USM) Students," International Journal of Management and Entrepreneurship, vol. 1, no. 1, pp. 8-20, 2005.

[8] M. Gelderen, M. Brand, M. Van Praag, W. Bodewes, E. Poutsman, and A. Van Gils, "Explaining Entrepreneurial Intentions by Means of The Theory of Planned Behavior," Career Development International, vol. 13, no. 6, pp. 538-559, 2008, doi: 10.1108/13620430810901688.

[9] A. Rasli, S. U. R. Khan, S. Malekifar, and S. Jabeen, "Factors Affecting Entrepreneurial Intention among Graduate Students of Universiti Teknologi Malaysia," International Journal of Business and Social Science, vol. 4, no. 2, pp. 182-188, 2013.

[10] F. Liñán, J. C. Rodríguez-Cohard and J. M. Rueda-Cantuche, "Factors Affecting Entrepreneurial Intention Levels: A Role for Education," International Entrepreneurship and Management Journal, vol. 7, no. 2, pp. 195-218, 2010, doi: 10.1007/s11365-010-0154-z.

[11] M. Hou, D. Liu, A. Wu and Z. Yan, "Will Entrepreneurial Intention Directly Lead to Entrepreneurial Behaviour? A Study Based on The Intermediary Effect of Entrepreneurial Implementation Plan," Second International Conference on Economic and Business Management (FEBM 2017). Atlantis Press, vol. 33, 2017, pp. 89-95, doi: 10.2991/febm-17.2017.12.

[12] M. Beynon, P. Jones, D. Pickernell and G. Maas, "Investigating Total Entrepreneurial Activity and Entrepreneurial Intention in Africa Regions Using Fuzzy-Set Qualitative Comparative Analysis (fsQCA)," Small Enterprise Research, vol. 27, no. 2, pp. 1-19, 2020.

[13] S. Delanoë-Gueguen and F. Liñán, "A Longitudinal Analysis of The Influence of Career Motivations on Entrepreneurial Intention and Action," Canadian Journal of Administrative Sciences, vol. 36, no. 4, pp. 527-543, 2018, doi: 10.1002/cjas.1515.

[14] T. Moi, Y. L. Adeline, and M. L. Dyana, "Young Adult Responses to Entrepreneurial Intent," Researchers World, vol. 2, no. 3, pp. 37-52, 2011.

[15] N. Ozaralli and N. K. Rivenburgh, "Entrepreneurial Intention: Antecedents to Entrepreneurial Behavior in the U.S.A. and Turkey," Journal of Global Entrepreneurship Research, vol. 6, no. 1, pp. 1-32, 2016, doi: 10.1186/s40497-016-0047-x.

[16] R. Hu and Y. Ye, "Do Entrepreneurial Alertness and Self-Efficacy Predict Chinese Sports Major Students' Entrepreneurial Intention?" Social Behavior and Personality: An International Journal, vol. 45, no. 7, pp. 1187-1196, 2017, doi: 10.2224/sbp.6356.

[17] K. Alammari, R. Newbery, M. Y. Haddoud, and E. Beaumont, "Post-Materialistic Values and Entrepreneurial Intention-The Case of Saudi Arabia," Journal of Small Business and Enterprise Development, vol. 26, no. 1, pp. 158-179, 2019, doi: 10.1108/JSBED-12-2017-0386.

[18] V. K. Nsahlai, L. J. Zogli, E. Lawa, and B. I. Dlamini, "Factors Influencing Entrepreneurial Intention: A Case of Students in A South African University," Academy of Entrepreneurship Journal, vol. 26, no. 1, pp. 1-10, 2020.

[19] J. H. Son, K. B. Jung, and N. Y. Lee, "The Impact of Entrepreneurial Self-Efficacy on the Entrepreneurial Intention of Preliminary Social Entrepreneurs and General Entrepreneurs: The Moderating Effect of Social Support," AsiaPacific Journal of Business Venturing and Entrepreneurship, vol. 13, no. 1, pp. 89-104, 2018.

[20] N. Shiri, D. Mohammadi, and S. M. Hosseini, "Entrepreneurial Intention of Agricultural Students: Effects of Role Model, Social Support, Social Norms and Perceived Desirability," Archives of Applied Science Research, vol. 4, no. 2, pp. 892-897, 2012

[21] M. B. A. Kadir, M. Salim, and H. Kamarudin, "The Relationship between Educational Support and Entrepreneurial Intentions in Malaysian Higher Learning Institution," Procedia-Social and Behavioral Sciences, vol. 69, pp. 2164-2173, 2012, 10.1016/j.sbspro.2012.12.182.

[22] S.E. Taylor, "Social Support: A Review," in M.S. Friedman, Ed., The Handbook of Health Psychology. Oxford University Press, New York, NY, 2011, pp. 189-214.

[23] L. F. Edelman, T. Manolova, G. Shirokova, and T. Tsukanova, "The Impact of Family Support on Young Entrepreneurs' Start-Up Activities," Journal of Business Venturing, vol. 31, no. 4, pp. 428-448, 2016, doi: https://doi.org/10.1016/j.jbusvent.2016.04.003. 
[24] M. M. Friedman, V. R. Bowden, and E. G. Jones, Family Nursing Textbooks: Research, Theory, and Practice (in Bahasa). Jakarta: Egc, 2010.

[25] R. A. Baron and D. Byrne, Social Psychology (in Bahasa). Jakarta: Erlangga, 2005.

[26] B. Smet, Health Psychology (in Bahasa). Jakarta: PT. Grasindo, 2004.

[27] E. P. Sarafino and T. W. Smith, Health Psychology, 8th Ed. USA: John Wiley \& Sons, Inc., 2014.

[28] P. Jaskiewicz, J. G. Combs, and S. B. Rau, "Entrepreneurial Legacy: Toward A Theory of How Some Family Firms Nurture Transgenerational Entrepreneurship," Journal of Business Venturing, vol. 30, no. 1, pp. 29-49, 2015, doi: 10.1016/j.jbusvent.2014.07.001.

[29] M. A. Sahban, M. Kumar, and S. S. Ramalu, "Instrument Development: Entrepreneurial Social Support Assessment Instrument (IESSA)," Research Journal of Economics \& Business Studies, vol. 4, no. 3, pp. 21-36, 2015.

[30] J. G. Harris, "Self-Esteem, Family Support, Peer Support, and Depressive Symptomatology: A Correlational Descriptive Study of Pregnant Adolescents," Dissertation, Georgia State University, 2006.

[31] L. Altinay, M. Madanoglu, R. Daniele, and C. Lashley, "The Influence of Family Tradition and Psychological Traits on Entrepreneurial Intention," International Journal of Hospitality Management, vol. 31, no. 2, pp. 489-499, 2012, doi: 10.1016/j.ijhm.2011.07.007.

[32] A. T. Karabulut, "Personality Traits on Entrepreneurial Intention," Procedia-Social and Behavioral Sciences, vol. 229, pp. 12-21, 2016, doi: 10.1016/j.sbspro.2016.07.109.

[33] A. Phares, Locus of Control, Personality. New Jersey: General Learning Press, 2016.

[34] H. M. Lefcourt, Locus of Control: Current Trends in Theory and Research. Hillsdale, NJ: Lawrence Erlbaum, 2001.

[35] A. I. Muslimah and Nurhalimah, "Aggressiveness in Terms of Internal Locus of Control in Students of SMP Negeri 1 Bekasi and Students of SMA 1 Patriot in Bekasi (in Bahasa)," Jurnal Ilmiah Psikologi Terapan, vol. 5, no. 2, pp. 34-54, 2012.

[36] R. Kreitner and A. Kinicki, Organizational Behavior (in Bahasa). Jakarta: Salemba Empat, 2005.

[37] S. P. Robbins and T. A. Judge, Organizational Behaviour. New Jersey: Prentice-Hall, 2007.

[38] H. M. Lefcourt, Locus of Control: Current Trends in Theory and Research. Hillsdale, NJ: Lawrence Erlbaum, 2001.

[39] M. Entrialgo, E. Fernández and C. J. Vázquez, "Characteristics of Managers as Determinants of Entrepreneurial Orientation: Some Spanish Evidence," Enterprise and Innovation Management Studies, vol. 1, no. 2, pp. 187-205, 2000, 10.1080/14632440050119596/.

[40] S. Kristiansen and N. Indarti, "Entrepreneurial Intention among Indonesian and Norwegian Students," Journal of Enterprising Culture, vol. 12, no. 01, pp. 55-78, 2004, 10.1142/S021849580400004X.

[41] R. Remeikiene, G. Startiene, and D. Dumciuviene, "Explaining Entrepreneurial Intention of University Students: The Role of Entrepreneurial Education," Active Citizenship by Knowledge Management \& Innovation: Proceedings of the Management, Knowledge and Learning International Conference, 2013, pp. 299-307.

[42] F. Tentama and F. Abdussalam, "Internal Locus of Control and Entrepreneurial Intention: A Study on Vocational High School Students," Journal of Education and Learning (EduLearn), vol. 14, no. 1, pp. 97-102, 2020, doi: 10.11591/edulearn.v14i1.13999.

[43] M. Gelderen, M. Brand, M. Van Praag, W. Bodewes, E. Poutsman and A. Van Gils, "Explaining Entrepreneurial Intentions by Means of The Theory of Planned Behavior," Career Development International, vol. 13, no. 6, pp. 538-559, 2008, doi: 10.1108/13620430810901688.

[44] S. C. Mat, S. M. Maat and N. Mohd, "Identifying Factors that Affecting The Entrepreneurial Intention among Engineering Technology Students,” Procedia-Social and Behavioral Sciences, vol. 211, pp. 1016-1022, Nov. 2015.

[45] Iskandarini, "The Impact of Entrepreneurial Barrier toward Entrepreneurial Intention for Decreasing Unemployment through Community Empowerment," Procedia-Social and Behavioral Sciences, vol. 115, pp. 166-174, 2014, doi: 10.1016/j.sbspro.2015.11.135.

[46] R. Badri and N. Hachicha, "Entrepreneurship Education and Its Impact on Students' Intention to Start Up: A Sample Case Study of Students from Two Tunisian Universities," The International Journal of Management Education, vol. 17, no. 2, pp. 182-190, 2019, doi: 10.1016/j.ijme.2019.02.004.

[47] F. B. Zapkau, C. Schwens, H. Steinmetz, and R. Kabst, "Disentangling The Effect of Prior Entrepreneurial Exposure on Entrepreneurial Intention,” Journal of Business Research, vol. 68, no. 3, pp. 639-653, 2015, doi: 10.1016/j.jbusres.2014.08.007.

[48] M. R. M. Ahmed and K. Kayat, "Examining The Moderating Effect of Entrepreneurship Education on The Relationship between Entrepreneurial Self-Efficacy, Family Support, Friends Support and Entrepreneurial Intention of Final Year Female Tourism Undergraduate Students in Egypt," Journal of Global Economics, Management and Business Research, vol. 12, no. 1, pp. 1-21, 2020.

[49] A. Periera, N. A. Mashabi, and M. Muhariati, "The influence of parental support on children's interest in entrepreneurship (in students of SMK Strada Koja, North Jakarta)," (in Bahasa), Jurnal Kesejahteraan Keluarga dan Pendidikan (JKKP), vol. 4, no. 02, pp. 70-76, 2017, doi: 10.21009/JKKP.042.04.

[50] M. S. Farooq, M. Salam, S. Rehman, A. Fayolle, N. Jaafar, and K. Ayupp, "Impact of Support from Social Network on Entrepreneurial Intention of Fresh Business Graduates," Education + Training, vol. 60, no. 4, pp. 335-353, 2018, doi: 10.1108/et-06-2017-0092.

[51] D. Turker and S. S. Selcuk, "Which Factors Affect Entrepreneurial Intention of University Students?" Journal of European Industrial Training, vol. 33 no. 2, pp. 142-15, 2009, doi: 10.1108/03090590910939049. 
[52] I. Ajzen, "Perceived Behavioral Control, Self-Efficacy, Locus of Control, and The Theory of Planned Behavior," Journal of Applied Social Psychology, vol. 32, no. 4, pp. 665-683, 2002, doi: 10.1111/j.1559-1816.2002.tb00236.x.

[53] F. Liñán and F. J. Santos, "Does Social Capital Affect Entrepreneurial Intentions?" International Advances in Economic Research, vol. 13, no. 4, pp. 443-453, 2007, doi: 10.1007/s11294-007-9109-8.

[54] Y. Chen and Y. He, "The Impact of Strong Ties on Entrepreneurial Intention," Journal of Chinese Entrepreneurship, vol. 3, no. 2, pp. 147-158, 2011, doi: 10.1108/17561391111144573.

[55] H. M. Gelaidan and A. O. Abdullateef, "Entrepreneurial Intentions of Business Students in Malaysia," Journal of Small Business and Enterprise Development, vol. 24, no. 1, pp. 54-67, 2017, doi: 10.1108/jsbed-06-2016-0078.

[56] C. Odoardi, M. Galletta, A. Battistelli, and N. Cangialosi, "Effects of Beliefs, Motivation and Entrepreneurial SelfEfficacy on Entrepreneurial Intentions: The Moderating Role of Family Support," Annals of Psychology, vol. 21, no. 3, pp. 185-205, 2019.

[57] O. Brunel, E. M. Laviolette and M. Radu-Lefebvre, "Role Models and Entrepreneurial Intention: The Moderating Effects of Experience, Locus of Control and Self-Esteem," Journal of Enterprising Culture, vol. 25, no. 02, pp. 149-177, 2017, doi: 10.1142/S0218495817500066.

[58] A. Göksel and B. Aydıntan, "Gender, Business Education, Family Background and Personal Traits: A Multi Dimensional Analysis of their Affects on Entrepreneurial Propensity: Findings from Turkey," International Journal of Business and Social Science, vol. 2, no. 13, pp. 35-48, 2011.

[59] T. Hsiung, "Satisfaction with Entrepreneurial Education and Entrepreneurial Intention: The Moderating Role of Internal Locus of Control," International Journal of Education and Research, vol. 6, no. 4, pp. 139-146, 2018.

[60] E. Gurel, L. Altinay and R. Daniele, "Tourism Students' Entrepreneurial Intentions," Annals of Tourism Research, vol. 37, no. 3, pp. 646-669, 2010.

[61] A. Rauch, and M. Frese, "Born to be an Entrepreneur? Revisiting the Personality Approach to Entrepreneurship," in J. R. Baum, M. Frese, and R. A. Baron, Eds., The organizational frontiers. The Psychology of Entrepreneurship. Lawrence Erlbaum Associates, 2007, pp. 41-65.

[62] M. Obschonka, R. K. Silbereisen, and E. Schmitt-Rodermund, "Entrepreneurial Intention as Developmental Outcome," Journal of Vocational Behavior, vol. 77, no. 1, pp. 63-72, 2010, doi: 10.1016/j.jvb.2010.02.008.

[63] F. Tentama, S. A. Mulasari, Subardjo and S. Widiasari, "Entrepreneurship Education to Improve Entrepreneurship Intention," Humanities \& Social Sciences Reviews, vol. 7, no. 3, pp. 62-168, 2019, doi: 10.18510/hssr.2019.7325.

[64] F. Tentama and T. H. Paputungan, "Entrepreneurial Intention of Students Reviewed from Self-Efficacy and Family Support in Vocational High School," International Journal of Evaluation and Research in Education (IJERE), vol. 8, no. 3, pp. 557-562, 2019, doi: 10.11591/ijere.v8i3.20240.

[65] F. Tentama, R. Jiamsari, L. Efliyulia and S. L. Qodrati, "Students' Entrepreneurial Intention Viewed from Subjective Norms and Hardiness in Vocational High Schools in Yogyakarta," International Journal of Scientific \& Technology Research, vol. 8, no. 12, pp. 2820-2824, 2019.

[66] S. A. Mulasari, F. Tentama, Subardjo, Sulistyawati, D. R. Kusuma and T. W. Sukesi, "Entrepreneurial Behavior in Entrepreneurial Pioneer in Ngalang Village," International Journal of Scientific \& Technology Research, vol. 8, no. 12, pp. 2038-2045, 2019. 